\title{
GH substitution reverses the growth phenotype but not the defective ossification in thyroid hormone receptor $\alpha 1-/-\beta-/-$ mice
}

\author{
J M Kindblom ${ }^{1,4}$, S Göthe ${ }^{2}$, D Forrest ${ }^{3}$, J Törnell ${ }^{1,4}$, \\ B Vennström ${ }^{2}$ and C Ohlsson ${ }^{1}$ \\ ${ }^{1}$ Research Center of Endocrinology and Metabolism, Department of Internal Medicine, Sahlgrenska University Hospital, Gothenburg, Sweden \\ ${ }^{2}$ Department of Cell and Molecular Biology, Karolinska Institute, Stockholm, Sweden \\ ${ }^{3}$ Department of Human Genetics, Mount Sinai School of Medicine, New York, New York, USA \\ ${ }^{4}$ AstraZeneca Transgenic Center, AstraZeneca R\&D, Mölndal, Sweden \\ (Requests for offprints should be addressed to C Ohlsson, Department of Internal Medicine, Division of Endocrinology, RCEM, Sahlgrenska University Hospital, \\ S-413 45 Göteborg, Sweden; Email: claes.ohlsson@medic.gu.se) \\ (J M Kindbloom and S Göthe contributed equally to this work)
}

\begin{abstract}
Thyroid hormone receptor $\alpha 1, \beta 1$ and $\beta 2$-deficient mice (TR $\alpha 1-/-\beta-/-$ mice) demonstrate growth retardation and defective ossification in the epiphyses associated with an inhibition of the GH/IGF-I axis. There are differences between TR $\alpha 1-/-\beta-/-$ mice (receptor deficient) and the hypothyroid animal model (ligand deficient). Such differences include possible repressive actions exerted by unliganded receptors in the ligand-deficient (hypothyroid) model but not in the receptor-deficient model. In the present study we have investigated whether or not GH substitution rescues the skeletal phenotype of TR $\alpha 1-/-\beta-/-$ mice.

TR $\alpha 1-/-\beta-/-$ and wild-type (WT) mice were treated with $\mathrm{GH}$ from day 18 until 10 weeks of age. GH substitution of mutant mice resulted in a significant and sustained stimulatory effect on the body weight that was
\end{abstract}

not seen in WT mice. GH-treated mutant mice but not GH-treated WT mice demonstrated increased length and periosteal circumference of the femur. However, GH substitution did not reverse the defective ossification seen in TR $\alpha 1-/-\beta-/-$ mice. TR $\alpha 1-/-\beta-/-$ mice displayed increased width of the proximal tibial growth plate, which was caused by increased width of the proliferative but not the hypertrophic layer. GH substitution did not restore the disturbed morphology of the growth plate in TR $\alpha 1-/-\beta-/-$ mice.

In summary, GH substitution reverses the growth phenotype but not the defective ossification in TR $\alpha 1-/-\beta-/-$ mice. Our data suggest that TRs are of importance both for the regulation of the GH/IGF-I axis and for direct effects on cartilage.

Journal of Endocrinology (2001) 171, 15-22

\section{Introduction}

Thyroid hormone, tri-iodothyronine $\left(\mathrm{T}_{3}\right)$, is involved in a wide variety of physiological and developmental processes including regulation of basal metabolism, development of the central nervous system, and the growth and remodeling of bone. Childhood onset hypothyroidism results in growth retardation (Abbassi et al. 1980) and hyperthyroidism is associated with adult bone loss (Fraser et al. 1971).

Thyroid hormone signaling is mediated via thyroid hormone receptors $\operatorname{TR} \alpha$ and $\operatorname{TR} \beta$ (Sap et al. 1986). TR $\alpha 1$, TR $\alpha 2$ and TR $\beta 1$ are expressed by osteoblasts and chondrocytes, and TR $\alpha 2$ and TR $\beta 1$ are expressed by osteoclasts in human bone (Abu et al. 1997). Two mechanisms of action have been proposed: (i) a direct action of TRs in bone and cartilage, or (ii) an indirect effect via regulation of the growth hormone $(\mathrm{GH})$ /insulin-like growth factor-I (IGF-I) axis (Ohlsson et al. 1993). To understand the role of thyroid hormones and their receptors, mice deficient in the expression of one or several TR isoforms have been developed. No overt skeletal phenotype or growth retardation has been reported for TR $\beta-/-$ or TR $\alpha 1-/-$ mice (Forrest et al. 1996, Wikstrom et al. 1998). In contrast, mice lacking both TR $\alpha 1$ and $\alpha 2$ (TR $\alpha-/-)$ have an impaired epiphyseal ossification and are growth arrested (Fraichard et al. 1997, Gauthier et al. 1999). These mice are reported to exhibit identical skeletal phenotype to the one observed in TR $\alpha-/-\beta-/-$ compound mice (Gauthier et al. 1999). These findings indicate that separate roles might exist for the different TR subtypes in the regulation of growth and development.

The effects of $\mathrm{GH}$ on the growth plate and bone involve both direct and indirect effects via local or systemic IGF-I (Ohlsson et al. 1998, Sjogren et al. 1999). $\mathrm{GH}$ and $\mathrm{T}_{3}$ 
interact in the stimulation of longitudinal bone growth and bone maturation. The crosstalk between the $\mathrm{GH}$ and $\mathrm{T}_{3}$ pathways occurs at several levels, and includes both $\mathrm{T}_{3}$-mediated regulation of $\mathrm{GH}$ gene transcription (Sap et al. 1990, Schaufele et al. 1992) and stimulation of IGF-I expression (Lewinson et al. 1994, Varga et al. 1994, Huang et al. 2000, Lakatos et al. 2000).

We have previously reported pre- and postnatal growth retardation and defective ossification in TR $\alpha 1-/-\beta-/-$ mice. These findings were associated with decreased pituitary content of GH mRNA and protein as well as decreased serum levels of IGF-I (Göthe et al. 1999). Therefore the aim of the present study was to investigate whether or not GH substitution rescues the skeletal phenotype of TR $\alpha 1-/-\beta-/-$ mice.

\section{Materials and Methods}

\section{Mouse strains}

Mice were generated and genotyped as previously described (Forrest et al. 1996, Wikstrom et al. 1998, Gothe et al. 1999). Mice were housed under $12 \mathrm{~h}$ light: $12 \mathrm{~h}$ darkness cycles in a controlled environment with $40-50 \%$ relative humidity at $22^{\circ} \mathrm{C}$.

All animal experiments were performed under approved protocols.

\section{GH injections and body weights}

Male TR $\alpha 1-/-\beta-/-$ (hereafter referred to as knock out $(\mathrm{KO})$ ) and wild-type (WT) pups were divided into four groups receiving either saline or GH (human GH; Pharmacia \& Upjohn, Stockholm, Sweden): $n=10$ for the WT and saline group; $n=9$ for the WT and GH group; $n=9$ for the KO and saline group; and $n=8$ for the KO and GH group. From day 18 postnatally (P18; P13 to P20) until P40 (P36 to P43), mice were given a daily s.c. dose of $1.5 \mathrm{mg} / \mathrm{kg} \mathrm{GH}$ or saline. Serum levels of IGF-I were measured to determine whether or not the dose given reversed the GH deficiency. From day P41 (P37 to P44) to day P67 (P63 to 70), the mice were given a daily dose of $3.8 \mathrm{mg} / \mathrm{kg} \mathrm{GH}$ s.c.. The mice were thereafter anesthetized and killed by heart puncture.

\section{Serum parameters}

Serum IGF-I levels were measured by double-antibody IGF-binding protein-blocked RIA (Blum \& Breier 1994).

\section{Dual X-ray absorptiometry (DXA)}

Areal bone mineral content (BMC) and areal bone mineral density (BMD) $\left(\mathrm{BMC} / \mathrm{cm}^{2}\right)$ were measured using the Norland pDEXA Sabre (Norland Medical Systems, Fort
Atkinson, WI, USA) with Sabre Research 3.6 software. In vivo measurements were performed on 10-week-old anesthetized animals to measure total body BMC. A maximum of three mice could be analyzed in the same scan. To avoid interscan variations, a WT mouse was included as an internal control in each scan. Medium resolution scans were performed (line-spacing $0.05 \mathrm{~cm}$ ). Ex vivo measurements of the left femur were performed on excised bones placed on a $1 \mathrm{~cm}$ thick Plexiglas table (line spacing: tibia and femur $0.02 \mathrm{~cm}$, vertebrae $0.01 \mathrm{~cm}$ ).

\section{Peripheral quantitative computerized tomography ( $p Q C T$ )}

Tomographic measurements were performed using the STRATEC pQCT XCT (software version 5.4B; Norland Medical Systems) operating at a resolution of $70 \mu \mathrm{m}$ as previously described (Windahl et al. 1999). Mid-diaphyseal pQCT scans of the left femora were performed to determine cortical BMD, cortical area, cortical thickness, periosteal circumference and endosteal circumference. The mid-diaphyseal region of femora in mice contains only cortical bone. Metaphyseal pQCT scans of the left femora were performed to measure trabecular volumetric BMD. The metaphyseal scan was positioned $4 \%$ of the total length of the femur proximal to the distal growth plate (an area consisting of a central portion of trabecular bone). The trabecular bone was defined by setting an inner threshold to $45 \%$ of the total area. The interassay coefficients of variation for the pQCT measurements were $<2 \%$.

\section{Histological staining and growth plate measurements}

Right femora were excised and fixed in $4 \%$ buffered paraformaldehyde and subsequently decalcified, embedded in paraffin and sectioned. Sections were stained with Alcian Blue/Van Gieson stain. The width of growth plates were measured using an image processing system (Easy Image; Bergströms Instruments, Stockholm, Sweden) coupled to a microscope. For measurements of total growth plate and the hypertrophic layer the average of 30 measurements was calculated. The width of the proliferative layer was calculated by subtracting the width of the hypertrophic layer from the width of the total growth plate. The observer was blinded to the treatment groups during these measurements.

\section{Fat measurements}

We have previously developed a combined DXA image analysis procedure for the in vivo prediction of fat content in mice (Ohlsson et al. 2000). The interassay coefficient of variation for the measurements of percent fat area was less than $3 \%$. 


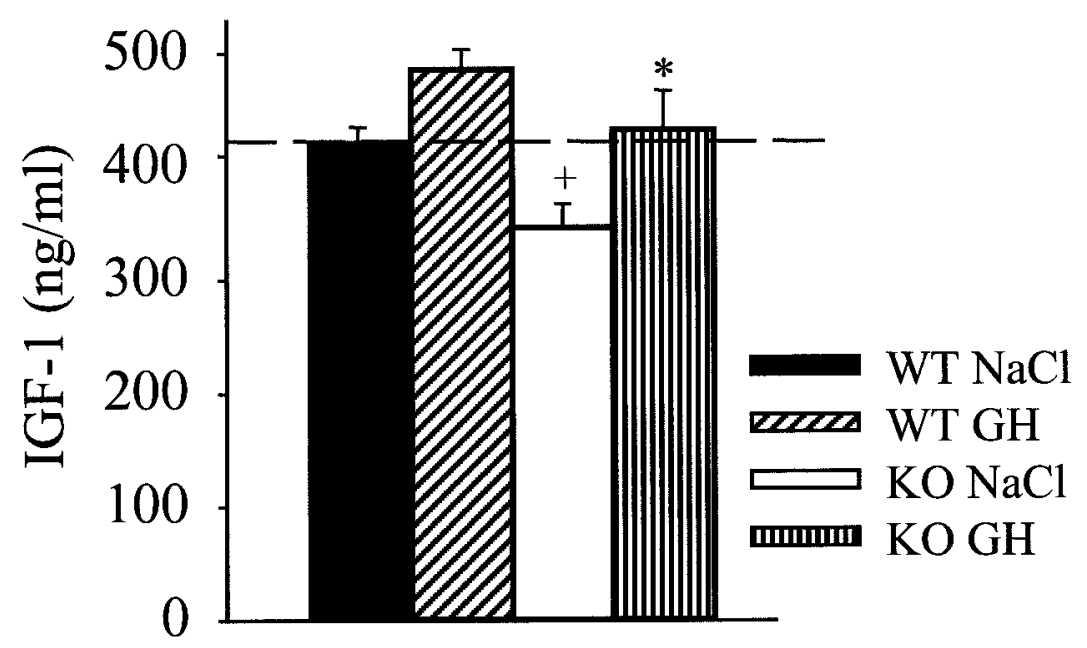

Figure 1 Serum IGF-I in 12-week-old KO mice. KO and WT mice were treated with GH for 10 weeks. ( $n=10$ for WT and saline; $n=9$ for WT and $\mathrm{GH} ; n=9$ for $\mathrm{KO}$ and saline; $n=8$ for $\mathrm{KO}$ and $\mathrm{GH}$.) Values are means \pm S.E.M. Data were analyzed by one-way ANOVA followed by a Student-Newman-Keuls multiple range test. ${ }^{*} P<0.05$ vs saline, ${ }^{+} P<0 \cdot 01$ vs WT.

\section{Results}

GH substitution normalizes the GH/IGF-I axis in KO mice

In the present study the objective was to give $\mathrm{KO}$ mice full substitution of $\mathrm{GH}$ in order to reverse the $\mathrm{GH}$ deficiency. In accord with our previous findings, serum levels of IGF-I were decreased in KO compared with WT mice $(-18 \%)$ (Fig. 1) (Gothe et al. 1999). To confirm that an adequate replacement dose of $\mathrm{GH}$ was used, serum IGF-I levels were measured. The initial dose of GH $(1.5 \mathrm{mg} / \mathrm{kg}$ per day) did not significantly increase serum IGF-I levels in the mutant mice and therefore the dose of $\mathrm{GH}$ was increased $(3.8 \mathrm{mg} / \mathrm{kg}$ per day). During the high-dose period the serum IGF-I levels were increased by $25 \%(P<0 \cdot 05)$ in the mutant mice, which represents a complete normalization as compared with WT mice (WT and saline, $421 \pm 13 \cdot 1 \mathrm{ng} / \mathrm{ml} ; \mathrm{KO}$ and $\mathrm{GH}$, $433 \pm 34 \cdot 6 \mathrm{ng} / \mathrm{ml}$ ) (Fig. 1).

\section{GH substitution reverses the growth phenotype in $\mathrm{KO}$ mice}

Similar to a previous report (Gothe et al. 1999), KO mice in the present study exhibited postnatal growth retardation which was reflected by a reduction in body weight $(-27 \%$, $P<0 \cdot 001)$ and a decrease in bone lengths, most pronounced in the femur $(-16 \%, P<0 \cdot 001)$. GH-substituted mutant mice demonstrated an $18 \%(P<0 \cdot 01)$ increase in body weight but were smaller than saline-treated WT mice (Fig. 2a). A detailed analysis of the effect of GH on body growth demonstrated that a significant and sustained stimulatory effect of $\mathrm{GH}$ was seen after 14 days of high-dose treatment in the mutant mice (Fig. 2b). WT mice did not exhibit significantly increased body growth in response to the given $\mathrm{GH}$ dose over the whole period, but showed a transient increase in body weight at day 41 of GH substitution (Fig. 2b). Two-way ANOVA of the whole period of GH substitution demonstrated that the $\mathrm{GH}$ effect was significantly larger in the mutant mice than in WT mice $(P<0 \cdot 05$; Fig. $2 \mathrm{~b})$. On a high dose of $\mathrm{GH}$ the mutant mice outgrew the saline-treated WT mice by $49 \%$. These findings show that GH substitution of mutant mice restores the normal increase in body weight. Furthermore, they also indicate that GH-treated mutant mice exhibit a catch-up growth.

DXA scans showed that GH substitution also increased the length of the femur by $6 \%(P<0 \cdot 01)$ and of total femoral area by $10 \%(P<0 \cdot 05)$ in the mutant mice, but failed to significantly alter these parameters in WT mice (Fig. 3a). Mid-diaphyseal pQCT scans of femora revealed increased periosteal cortical circumference in response to $\mathrm{GH}$ substitution in mutant mice, but not in WT mice (Table 1). Furthermore, the cross-sectional cortical area was significantly reduced in saline- but not in GH-treated mutant mice (Table 1).

Thus, our results demonstrate that GH substitution induces compensatory body growth and leads to a reversal of the growth phenotype in terms of body weight and dimensions of long bones in $\mathrm{KO}$ mice.

$\mathrm{GH}$ does not reverse the defective ossification in the epiphysis

In accord with our previous findings, KO mice in the present study have severe defects in epiphyseal ossification/mineralization (Gothe et al. 1999). GH 


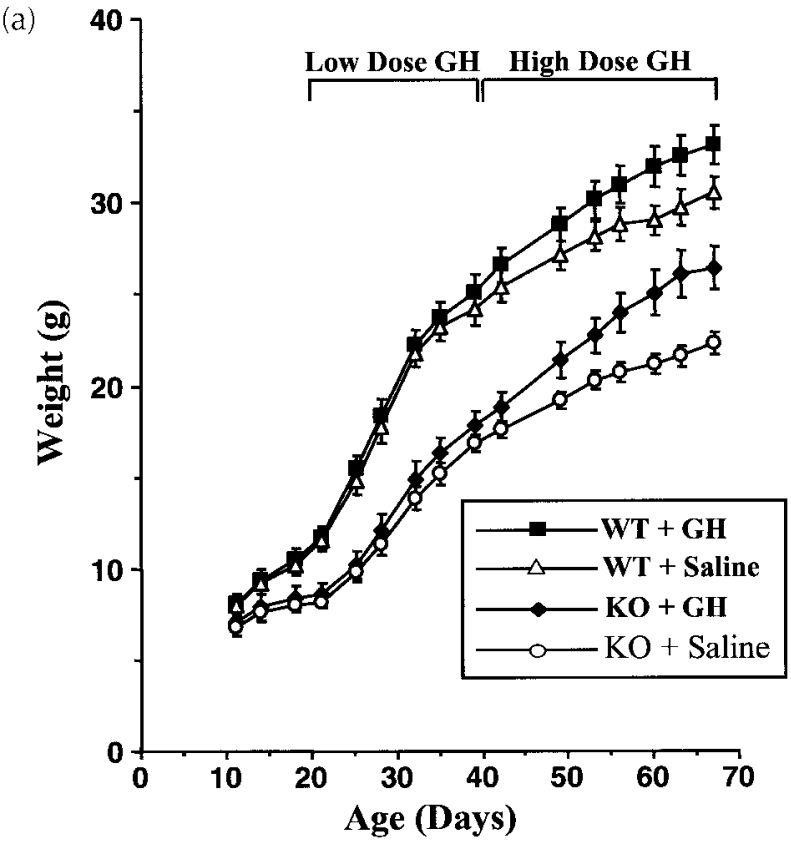

(b)

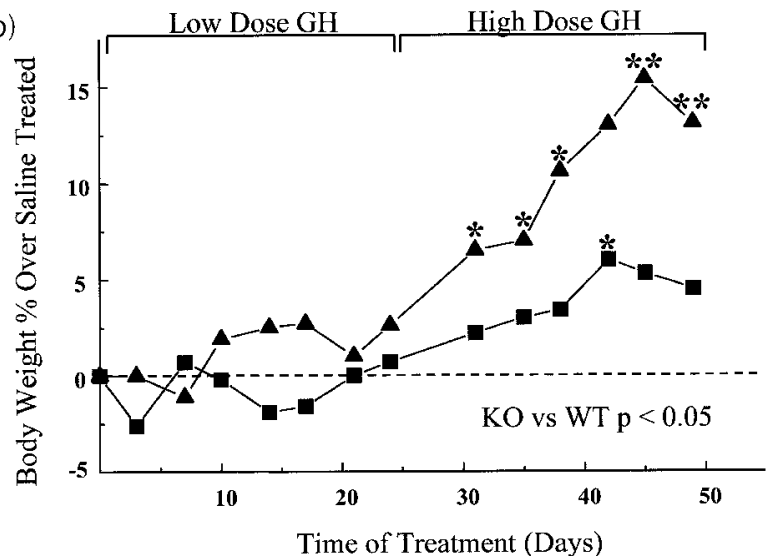

Figure 2 Effect of $\mathrm{GH}$ substitution on body weight in $\mathrm{KO}$ and WT mice. ( $n=9$ for $\mathrm{KO}$ and saline; $n=8$ for $\mathrm{KO}$ and $\mathrm{GH} ; n=10$ for WT and saline; $n=9$ for WT and GH.) (a) Weight gain over the whole period. Values are means \pm S.E.M. (b) Weight gain on high-dose GH in WT ( $\boldsymbol{\square})$ and $\mathrm{KO}(\boldsymbol{\Delta})$ mice. The effects are given as percent increase compared with saline-treated mice and values are given as means. The effect vs saline-treated mice at different times was calculated by one-way ANOVA followed by a Student-Newman-Keuls multiple range test. ${ }^{*} P<0 \cdot 05,{ }^{* *} P<0 \cdot 01$. To compare the $\mathrm{GH}$ effect in $\mathrm{KO}$ mice with that in WT mice a two-way ANOVA followed by a Student-Newman-Keuls multiple range test was performed for the high-dose period. The $P$ value for $\mathrm{KO}$ vs WT mice is indicated.

substitution did not normalize the maturational status of the epiphyseal bone in the mutant mice (Fig. 4). DXA scans revealed that areal BMD and BMC were reduced in the mutant mice but none of these parameters were significantly altered by GH substitution (Fig. 3b). Cortical

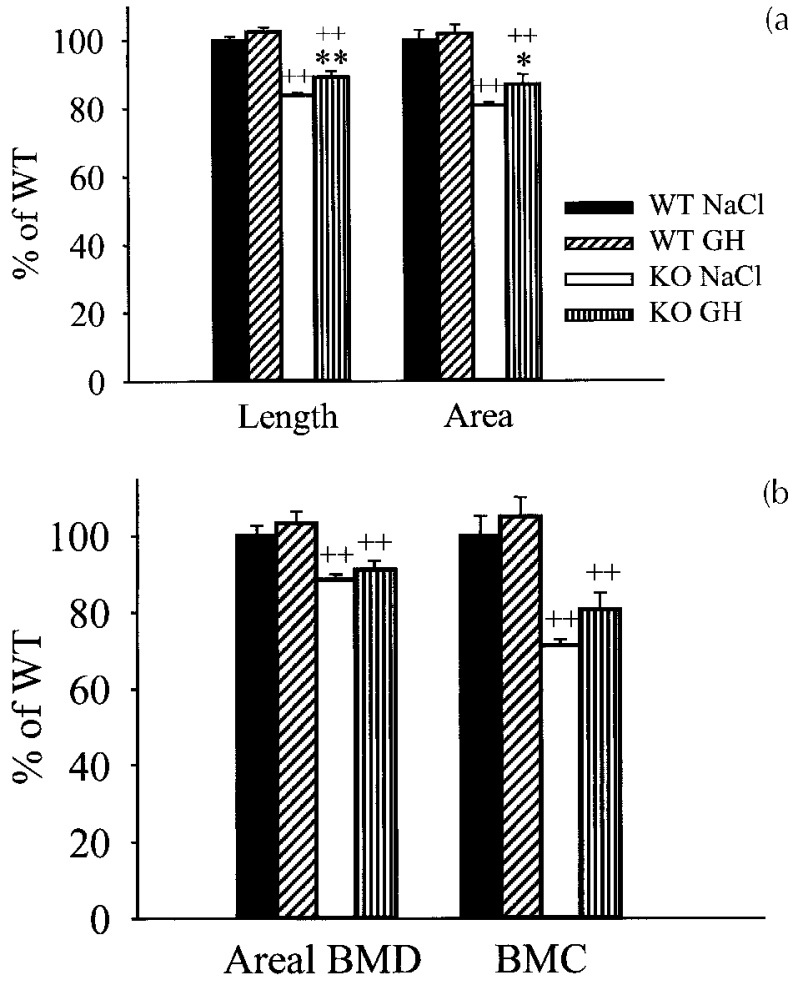

Figure 3 DXA measurements in 12-week-old $\mathrm{KO}$ mice. $\mathrm{KO}$ and WT mice were treated with GH for 10 weeks. $(n=10$ for WT and saline; $n=9$ for WT and $\mathrm{GH} ; n=9$ for $\mathrm{KO}$ and saline; $n=8$ for $\mathrm{KO}$ and $\mathrm{GH}$.) Values are expressed as percent of WT as means \pm S.E.M. Data were analyzed by one-way ANOVA followed by a Student-Newman-Keuls multiple range test. ${ }^{*} P<0 \cdot 05,{ }^{* *} P<0 \cdot 01$ vs saline; ${ }^{++} P<0 \cdot 01$ vs WT. (a) Dimensional parameters of the femur; (b) areal $\mathrm{BMD}$ and $\mathrm{BMC}$ of the femur.

as well as trabecular volumetric density as measured with pQCT in the femur (Table 1) were reduced in the mutant mice, and again $\mathrm{GH}$ substitution did not reverse this phenotype. Thus, GH substitution neither reverses the defective ossification in the epiphysis nor the decreased areal $\mathrm{BMD}$ and $\mathrm{BMC}$ of the femur in $\mathrm{KO}$ mice.

Disturbed relationship between hypertrophy and proliferation in the growth plate

The present study revealed that KO mice exhibit a 10\% wider epiphyseal growth plate of the distal femur compared with WT mice (Fig. 5). This finding is reflected by an increased width of the proliferative layer $(28 \%)$. In contrast, the hypertrophic layer is diminished by $8 \%$ in the mutant mice (Fig. 5). GH substitution affected neither the total growth plate width nor the width of the individual layers in the mutant mice.

\section{Weight of other tissues and organs}

The liver, kidneys, spleen, heart and testes were weighed and correlated to body weight at the termination of the 
Table 1 pQCT measurements (means \pm S.E.M.) of left femora in 12-week-old mice. KO and WT mice were treated with GH for 10 weeks

\begin{tabular}{|c|c|c|c|c|}
\hline & \multicolumn{2}{|l|}{ WT } & \multicolumn{2}{|l|}{ КО } \\
\hline & Saline $(n=10)$ & $\mathrm{GH}(n=9)$ & Saline $(n=9)$ & $\mathrm{GH}(n=8)$ \\
\hline Trabecular density $\left(\mathrm{mg} / \mathrm{mm}^{3}\right)$ & $335 \pm 34$ & $293 \pm 28$ & $250 \pm 19^{+}$ & $225 \pm 12$ \\
\hline Cortical density $\left(\mathrm{mg} / \mathrm{mm}^{3}\right)$ & $1287 \pm 9 \cdot 3$ & $1304 \pm 4.9$ & $1231 \pm 11 \cdot 4^{++}$ & $1220 \pm 7 \cdot 1^{++}$ \\
\hline Cortical area $\left(\mathrm{mm}^{2}\right)$ & $1 \cdot 33 \pm 0.074$ & $1 \cdot 34 \pm 0 \cdot 060$ & $1 \cdot 13 \pm 0.033^{+}$ & $1 \cdot 25 \pm 0 \cdot 052$ \\
\hline Cortical endosteal circumference $(\mathrm{mm})$ & $3 \cdot 62 \pm 0 \cdot 069$ & $3 \cdot 68 \pm 0.062$ & $3 \cdot 28 \pm 0 \cdot 048^{++}$ & $3 \cdot 40 \pm 0 \cdot 060^{++}$ \\
\hline
\end{tabular}

Data were analyzed by one-way ANOVA followed by a Student-Newman-Keuls multiple range test. ${ }^{*} P<0 \cdot 05$ vs saline; ${ }^{+} P<0 \cdot 05,{ }^{++} P<0 \cdot 01$ vs WT.

$\mathrm{NaCl}$
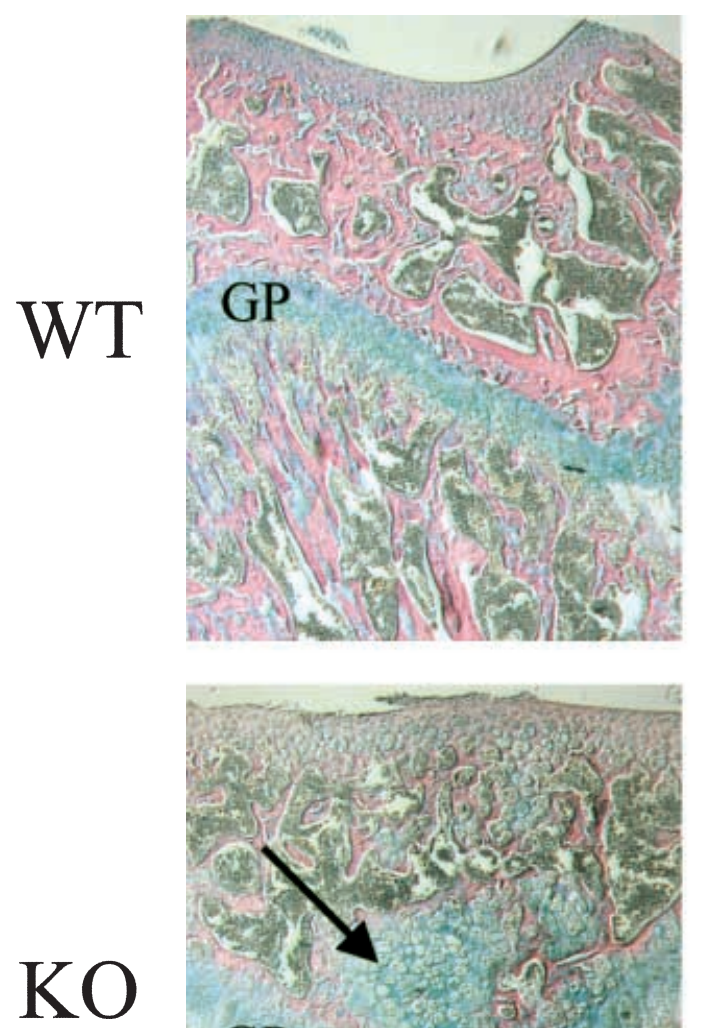

$\mathrm{GH}$
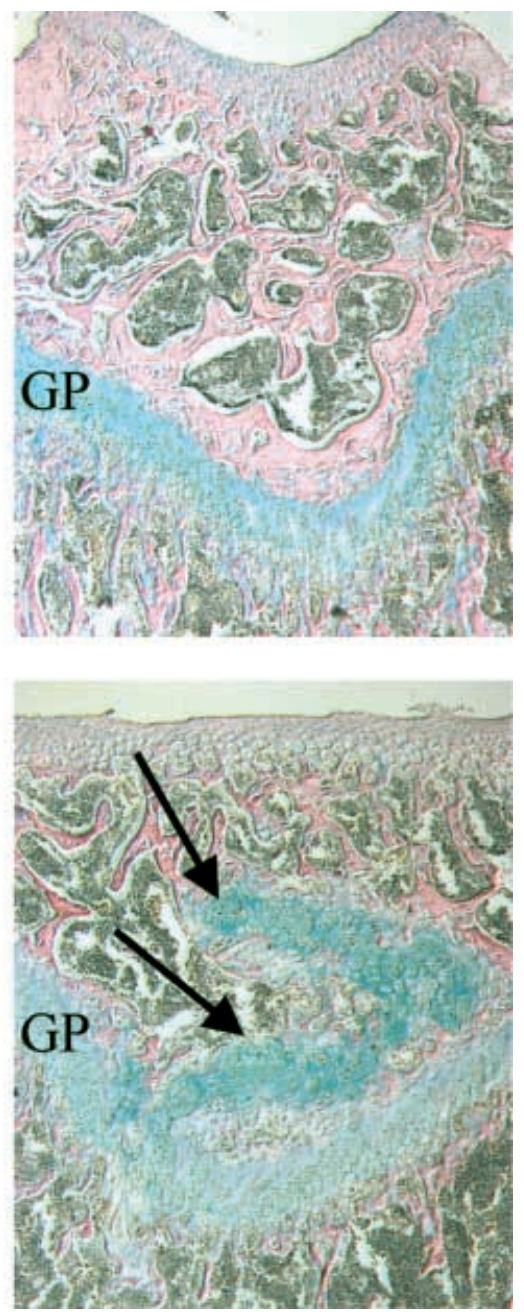

Figure 4 Disturbed ossification in the epiphysis in 10-week-old saline- and GH-treated KO mice. Alcian Blue/Van Gieson staining of sections from the femur. Arrow indicates cartilaginous area within the epiphyseal region. GP=growth plate. 


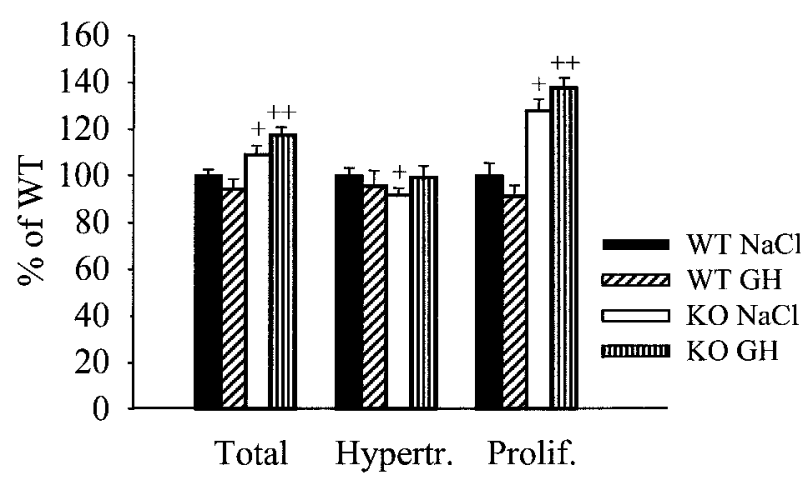

Figure 5 Width of distal femoral growth plates in 12-week-old KO mice. $\mathrm{KO}$ and WT mice were treated with $\mathrm{GH}$ for 10 weeks. $(n=10$ for WT and saline; $n=9$ for WT and $\mathrm{GH} ; n=9$ for $\mathrm{KO}$ and saline; $n=8$ for $\mathrm{KO}$ and $\mathrm{GH}$.) Values are expressed as percent of WT as means \pm S.E.M. Data were analyzed by one-way ANOVA followed by a Student-Newman-Keuls multiple range test. ${ }^{+} P<0 \cdot 05,{ }^{++} P<0 \cdot 01$ vs WT.

study. The relative weight of the testes was markedly increased by $86 \%$ in the mutant mice (Table 2). The relative weight of the liver was increased by $10 \%$, whereas that of the kidneys and spleen was reduced by 8 and $23 \%$ respectively in the mutant mice (Table 2). The relative weight of the kidneys, heart and testes decreased after GH substitution (Table 2).

\section{Fat content in the mutant mice}

Fat content was measured in age-matched 3- to 5-monthold mice $(n=15$ for KO, $n=16$ for WT) using DXA scans. This measurement demonstrated a 60\% reduction in DXA fat content in KO mice $(P<0 \cdot 05$, Student's $t$-test; Fig. 6). The fat content was unaffected by GH substitution (data not shown).

\section{Discussion}

TR $\alpha 1-/-\beta-/-$ mice display a severe skeletal phenotype with growth retardation and defective ossification of the

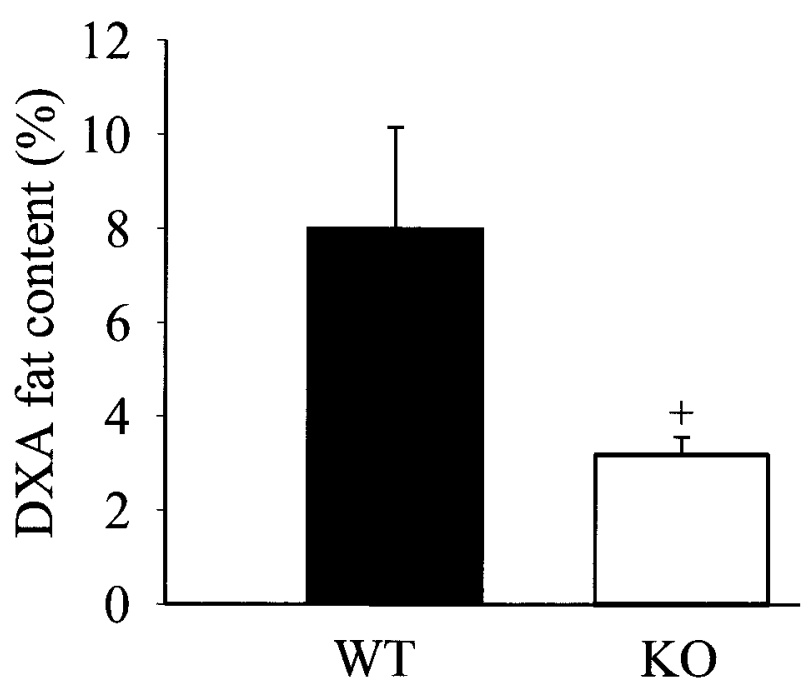

Figure 6 DXA fat content in 12-week-old KO mice. KO and WT mice were treated with $\mathrm{GH}$ for 10 weeks. $(n=10$ for WT and saline; $n=9$ for WT and $\mathrm{GH} ; n=9$ for $\mathrm{KO}$ and saline; $n=8$ for $\mathrm{KO}$ and $\mathrm{GH}$.) Values are expressed as percent of WT as means \pm S.E.M. Data were analyzed by one-way ANOVA followed by a Student-Newman-Keuls multiple range test. ${ }^{+} P<0 \cdot 05$ vs WT.

epiphysis. Such KO mice are also GH deficient as evidenced by low serum IGF-I levels and low pituitary content of GH mRNA and protein (Gothe et al. 1999). In the current study we demonstrated that KO but not WT mice responded to $\mathrm{GH}$ substitution with significantly increased body weight as well as increased longitudinal bone growth. In contrast, the defective ossification in $\mathrm{KO}$ mice was unaffected by GH substitution. We believe that the difference in body weight that persisted in the mutant mice after GH substitution is likely to have arisen before $\mathrm{GH}$ substitution was initiated and during the first period of a low and insufficient dose of GH. On high doses of GH, KO mice outgrew both the saline- and GH-treated WT mice, indicating catch-up growth. GH also affected the dimensions of the long bones, such as the length and periosteal circumference in the mutant mice but not in WT mice. These findings are in accord with the known

Table 2 Weights of visceral organs in 12-week-old mice. KO and WT mice were treated with GH for 10 weeks. Values are expressed as percent body weight \pm S.E.M.

\begin{tabular}{|c|c|c|c|c|}
\hline & \multicolumn{2}{|l|}{ WT } & \multicolumn{2}{|l|}{ KO } \\
\hline & Saline $(n=10)$ & $\mathrm{GH}(n=9)$ & Saline $(n=9)$ & $\mathrm{GH}(n=8)$ \\
\hline Liver & $5 \cdot 09 \pm 0 \cdot 16$ & $5 \cdot 47 \pm 0 \cdot 16$ & $5 \cdot 62 \pm 0 \cdot 13^{+}$ & $5 \cdot 58 \pm 0 \cdot 28$ \\
\hline Kidney & $1 \cdot 62 \pm 0 \cdot 047$ & $1 \cdot 55 \pm 0.041$ & $1.50 \pm 0.025^{+}$ & $1 \cdot 36 \pm 0.036^{* *++}$ \\
\hline Spleen & $0 \cdot 44 \pm 0 \cdot 021$ & $0 \cdot 42 \pm 0 \cdot 020$ & $0 \cdot 34 \pm 0 \cdot 014^{++}$ & $0 \cdot 35 \pm 0 \cdot 019^{+}$ \\
\hline Heart & $0 \cdot 51 \pm 0 \cdot 015$ & $0 \cdot 51 \pm 0 \cdot 018$ & $0 \cdot 49 \pm 0 \cdot 019$ & $0.42 \pm 0.008^{*^{++}}$ \\
\hline Testis & $0.56 \pm 0.029$ & $0.60 \pm 0.041$ & $1 \cdot 04 \pm 0.020^{++}$ & $0.92 \pm 0.038^{*++}$ \\
\hline
\end{tabular}

Data were analyzed by one-way ANOVA followed by a Student-Newman-Keuls multiple range test. ${ }^{*} P<0 \cdot 05,{ }^{* *} P<0 \cdot 01$ vs saline; ${ }^{+} P<0 \cdot 05,{ }^{++} P<0.01$ vs WT. 
effects of $\mathrm{GH}$ on bone, such as inducing longitudinal and periosteal bone growth (Andreassen et al. 1995, Ohlsson et al. 1998).

Studies on pubertal hypothyroid rats treated with human GH, have shown that GH substitution causes partial reversal of loss of body weight, while no effect of GH was seen on tibial length (Lewinson et al. 1989). The tibia has a different growth profile from the femur, with most of its longitudinal growth occurring before puberty. The femur, on the other hand, displays significant pubertal growth (Windahl et al. 1999). This difference between the tibia and the femur might explain why GH affected the growth of the femur in our study, but not tibial growth in the study using hypothyroid rats. Moreover, hypothyroid rats have decreased width of the growth plate due to a reduction in the number of proliferative cells and in the size of the hypertrophic cells (Lewinson et al. 1989). In contrast, total growth plate width in the distal femur was increased in $\mathrm{KO}$ mice as a result of a pronounced increased width of the proliferative layer but slightly reduced width of the hypertrophic layer. These findings indicate that loss of TR signaling leads to disturbed chondrocyte differentiation, resulting in a disruption in the balance between hypertrophy and proliferation in the growth plate. GH could not reverse the alterations in the growth plate seen in the mutant mice. It is important to consider the differences between the model for $T_{3}$ deficiency and the model for receptor deficiency. The TRs have been reported to exert $\mathrm{T}_{3}$-independent silencing of target genes in their unliganded state (Damm et al. 1989), and the relatively mild phenotype of $\mathrm{KO}$ mice as compared with hypothyroid WT mice has been explained by the transcriptional repressive effect of the unliganded receptor (Gothe et al. 1999). $T_{3}$ has also been proposed to have non-genomic activities (Davis \& Davis 1996); however, reducing the $\mathrm{T}_{3}$ serum levels of $\mathrm{KO}$ mice to below normal does not affect body weight of these mutant mice.

In contrast to the growth, no effect was seen on the skeletal maturation by $\mathrm{GH}$ substitution in adult $\mathrm{KO}$ mice. We therefore propose that $T_{3}$ induces skeletal maturation via a direct effect on cartilage. This notion is supported by previous reports on the effects of $\mathrm{T}_{3}$ on cultured growth plate chondrocytes, where $T_{3}$ has been shown to induce differentiation markers associated with ossification (Ohlsson et al. 1992, Alini et al. 1996, Robson et al. 2000).

The fat content, as measured with DXA, was decreased in KO mice. Thyroid hormone is known to affect the basal metabolism in almost all cells and pathological conditions in the thyroid axis often affect body weight. Hypothyroidism is frequently associated with increased fat mass and body weight, whereas weight loss is a pronounced sign in hyperthyroidism (Seppel et al. 1997, Miyakawa et al. 1999). As stated earlier there are important differences between the hypothyroid model and the receptor knock out model. However, it cannot be excluded that the diminished fat content in the mutant mice is secondary to the severe phenotype in the mutant mice.

The relative weight of the testes was dramatically increased in the mutant mice. Similarly, hypothyroidism has previously been associated with increased testicular weight, which was explained by increases in the number of Sertoli and Leydig cells (Hess et al. 1993, Cooke et al. 1996, Hardy et al. 1996). Further studies are necessary to elucidate the mechanisms for the enlargement of testes in $\mathrm{KO}$ mice. The relative weights of the kidney, heart and testis were reduced after GH substitution, presumably as a result of the rapid GH-induced body growth.

In conclusion, GH substitution reverses the growth phenotype but not the defective ossification in $\mathrm{KO}$ mice. Therefore we propose that TRs are of importance both for the regulation of the GH/IGF-I axis and for direct effects on cartilage.

\section{Acknowledgements}

This study was supported by the Swedish Medical Research Council (K2000-72X-13503-01A), the Swedish Foundation for Strategic Research, the Lundberg Foundation, the Swedish Association for Rheumatic Diseases, the Novo Nordisk Foundation, the Swedish Cancer Foundation, the Human Frontiers Science Program, AstraZeneca R\&D, Torsten and Ragnar Söderbergs Stiftelser, the Göteborg Medical Society and the March of Dimes Birth Defects Foundation.

\section{References}

Abbassi V, Rigterink E \& Cancellieri RP 1980 Clinical recognition of juvenile hypothyroidism in the early stage. Clinica Pediatrica 19 $782-786$

Abu EO, Bord S, Horner A, Chatterjee VK \& Compston JE 1997 The expression of thyroid hormone receptors in human bone. Bone 21 137-142.

Alini M, Kofsky Y, Wu W, Pidoux I \& Poole AR 1996 In serum-free culture thyroid hormones can induce full expression of chondrocyte hypertrophy leading to matrix calcification. Journal of Bone and Mineral Research 11 105-113.

Andreassen TT, Jorgensen PH, Flyvbjerg A, Orskov H \& Oxlund H 1995 Growth hormone stimulates bone formation and strength of cortical bone in aged rats. Journal of Bone and Mineral Research 10 1057-1067.

Blum WF \& Breier BH 1994 Radioimmunoassays for IGFs and IGFBPs. Growth Regulation 4 (Suppl 1) 11-19.

Cooke PS, Zhao YD \& Hansen LG 1996 Neonatal polychlorinated biphenyl treatment increases adult testis size and sperm production in the rat. Toxicology and Applied Pharmacology 136 112-117.

Damm K, Thompson CC \& Evans RM 1989 Protein encoded by $\mathrm{V}$-erbA functions as a thyroid-hormone receptor antagonist. Nature 339 593-597.

Davis PJ \& Davis FB 1996 Nongenomic actions of thyroid hormone. Thyroid 6 497-504.

Forrest D, Erway LC, Ng L, Altschuler R \& Curran T 1996 Thyroid hormone receptor beta is essential for development of auditory function. Nature Genetics 13 354-357. 
Fraichard A, Chassande O, Plateroti M, Roux JP, Trouillas J, Dehay C, Legrand C, Gauthier K, Kedinger M, Malaval L, Rousset B \& Samarut J 1997 The T3R alpha gene encoding a thyroid hormone receptor is essential for post-natal development and thyroid hormone production. EMBO Journal 16 4412-4420.

Fraser SA, Anderson JB, Smith DA \& Wilson GM 1971 Osteoporosis and fractures following thyrotoxicosis. Lancet 1 981-983.

Gauthier K, Chassande O, Plateroti M, Roux JP, Legrand C, Pain B, Rousset B, Weiss R, Trouillas J \& Samarut J 1999 Different functions for the thyroid hormone receptors $\operatorname{TR} \alpha$ and $\operatorname{TR} \beta$ in the control of thyroid hormone production and post-natal development. EMBO Journal 18 623-631.

Göthe S, Wang Z, Ng L, Kindblom JM, Barros AC, Ohlsson C, Vennstrom B \& Forrest D 1999 Mice devoid of all known thyroid hormone receptors are viable but exhibit disorders of the pituitarythyroid axis, growth, and bone maturation. Genes and Development 13 1329-1341.

Hardy MP, Sharma RS, Arambepola NK, Sottas CM, Russell LD, Bunick D, Hess RA \& Cooke PS 1996 Increased proliferation of Leydig cells induced by neonatal hypothyroidism in the rat. Journal of Andrology 17 231-238.

Hess RA, Cooke PS, Bunick D \& Kirby JD 1993 Adult testicular enlargement induced by neonatal hypothyroidism is accompanied by increased Sertoli and germ cell numbers. Endocrinology 132 2607-2613.

Huang BK, Golden LA, Tarjan G, Madison LD \& Stern PH 2000 Insulin-like growth factor I production is essential for anabolic effects of thyroid hormone in osteoblasts. Journal of Bone and Mineral Research 15 188-197.

Lakatos P, Foldes J, Nagy Z, Takacs I, Speer G, Horvath C, Mohan S, Baylink DJ \& Stern PH 2000 Serum insulin-like growth factor-I, insulin-like growth factor binding proteins, and bone mineral content in hyperthyroidism. Thyroid 10 417-423.

Lewinson D, Harel Z, Shenzer P, Silbermann M \& Hochberg Z 1989 Effect of thyroid hormone and growth hormone on recovery from hypothyroidism of epiphyseal growth plate cartilage and its adjacent bone. Endocrinology 124 937-945.

Lewinson D, Bialik GM \& Hochberg Z 1994 Differential effects of hypothyroidism on the cartilage and the osteogenic process in the mandibular condyle: recovery by growth hormone and thyroxine. Endocrinology 135 1504-1510.

Miyakawa M, Tsushima T, Murakami H, Isozaki O \& Takano K 1999 Serum leptin levels and bioelectrical impedance assessment of body composition in patients with Graves' disease and hypothyroidism. Endocrine Journal 46 665-673.

Ohlsson C, Nilsson A, Isaksson O, Bentham J \& Lindahl A 1992 Effects of tri-iodothyronine and insulin-like growth factor-I (IGF-I) on alkaline phosphatase activity, $\left[{ }^{3} \mathrm{H}\right]$ thymidine incorporation and
IGF-I receptor mRNA in cultured rat epiphyseal chondrocytes. Journal of Endocrinology 135 115-123.

Ohlsson C, Isgaard J, Tornell J, Nilsson A, Isaksson OG \& Lindahl A 1993 Endocrine regulation of longitudinal bone growth. Acta Paediatrica 82 (Suppl 391) 33-40.

Ohlsson C, Bengtsson BA, Isaksson OG, Andreassen TT \& Slootweg MC 1998 Growth hormone and bone. Endocrine Reviews 19 55-79.

Ohlsson C, Hellberg N, Parini P, Vidal O, Bohlooly M, Rudling M, Lindberg MK, Warner M, Angelin B \& Gustafsson JA 2000 Obesity and disturbed lipoprotein profile in estrogen receptoralpha-deficient male mice. Biochemical and Biophysical Research Communications 278 640-645.

Robson H, Siebler T, Stevens DA, Shalet SM \& Williams GR 2000 Thyroid hormone acts directly on growth plate chondrocytes to promote hypertrophic differentiation and inhibit clonal expansion and cell proliferation. Endocrinology 141 3887-3897.

Sap J, Munoz A, Damm K, Goldberg Y, Ghysdael J, Leutz A, Beug H \& Vennstrom B 1986 The c-erb-A protein is a high-affinity receptor for thyroid hormone. Nature 324 635-640.

Sap J, de Magistris L, Stunnenberg H \& Vennstrom B 1990 A major thyroid hormone response element in the third intron of the rat growth hormone gene. EMBO Journal 9 887-896.

Schaufele F, West BL \& Baxter JD 1992 Synergistic activation of the rat growth hormone promoter by Pit-1 and the thyroid hormone receptor. Molecular Endocrinology 6 656-665.

Seppel T, Kosel A \& Schlaghecke R 1997 Bioelectrical impedance assessment of body composition in thyroid disease. European Journal of Endocrinology 136 493-498.

Sjogren K, Liu JL, Blad K, Skrtic S, Vidal O, Wallenius V, LeRoith D, Tornell J, Isaksson OG, Jansson JO \& Ohlsson C 1999 Liverderived insulin-like growth factor I (IGF-I) is the principal source of IGF-I in blood but is not required for postnatal body growth in mice. PNAS 96 7088-7092.

Varga F, Rumpler M \& Klaushofer K 1994 Thyroid hormones increase insulin-like growth factor mRNA levels in the clonal osteoblastic cell line MC3T3-E1. FEBS Letters 345 67-70.

Wikstrom L, Johansson C, Salto C, Barlow C, Campos Barros A, Baas F, Forrest D, Thoren P \& Vennstrom B 1998 Abnormal heart rate and body temperature in mice lacking thyroid hormone receptor alpha 1. EMBO Journal 17 455-461.

Windahl SH, Vidal O, Andersson G, Gustafsson JA \& Ohlsson C 1999 Increased cortical bone mineral content but unchanged trabecular bone mineral density in female ERbeta(-/-) mice. Journal of Clinical Investigation 104 895-901.

Received 14 March 2001

Accepted 6 June 2001 